\title{
PERBEDAAN KADAR HEMOGLOBIN ANTARA ANAK USIA SEKOLAH YANG BERPRESTASI DAN YANG KURANG BERPRESTASI
}

\author{
${ }^{1}$ Petra Watuna \\ ${ }^{2}$ Max F. J. Mantik \\ ${ }^{2}$ Stefanus Gunawan
}

\author{
${ }^{1}$ Kandidat Skripsi Fakultas Kedokteran Universitas Sam Ratulangi Manado \\ ${ }^{2}$ Bagian Pediatri Fakultas Kedokteran Universitas Sam Ratulangi Manado \\ Email:Petrawatuna@yahoo.com
}

\begin{abstract}
Absrtact: The learning achievement of the students is influenced by various factors. These factors could be alone or together with other factors affecting the learning process thus causing a decrease in student achievement. Anemia, particularly iron deficiency anemia, is one of the major problems faced by the students and has a negative impact on students' performance and productivity. Anemia is a condition that indicates levels of hemoglobin (Hb) lower than normal. This is caused by lack of iron necessary for the formation of hemoglobin in the blood. The state of is caused by decreasing of oxygen-carrying capacity of red blood cells. This study aimed to determine the differences in hemoglobin levels among school-age children with high achievement and low achievement. This was a cross sectional analytical study by using the average value of mid semester for mathematics and science subjects in SMP 9 Pandu. The Kruskal-Wallis test in mathematics with Asymp. value Sig $0.746>0.05$ which meant that there was no difference in hemoglobin levels between students with high achievement and with low achievement. Physics subjects with Asymp. value Sig $0.028<0.05$ meant that there was a difference between hemoglobin levels of students with high achievement and with low achievement. Hemoglobin level did not affect the value of mathematics but affect the value of the physics.
\end{abstract}

Keywords: hemoglobin, iron deficiency, student achievement

\begin{abstract}
Abstrak: Capaian prestasi belajar para siswa dipengaruhi oleh berbagai faktor. Faktor-faktor tersebut bisa sendiri atau bersama dengan faktor lain mempengaruhi proses belajar sehingga menyebabkan penurunan prestasi siswa. Anemia, secara khusus anemia defisiensi besi adalah salah satu masalah utama yang dihadapi para siswa dan memiliki pengaruh negatif terhadap performa dan produktifitas siswa. Anemia adalah keadaan yang menunjukkan kadar hemoglobin $(\mathrm{Hb})$ seseorang lebih rendah dari kadar hemoglobin normal. Hal ini disebabkan oleh kekurangan zat besi yang diperlukan untuk pembentukan hemoglobin dalam tubuh. Keadaan anemia menyebabkan kapasitas pengangkutan oksigen oleh sel darah merah menurun. Tujuan penelitian ini untuk mengetahui bagaimana perbedaan kadar hemoglobin antara anak usia sekolah yang berprestasi dan kurang berprestasi. Penelitian ini bersifat analitik dengan pendekatan cross sectional, dengan mengambil rata-rata nilai mid semester untuk mata pelajaran matematika dan IPA di SMP 9 Pandu. Hasil penelitian: dengan uji Kruskal-Wallis pada mata pelajaran matematika dengan nilai Asymp. Sig 0,746 >0,05, artinya tidak terdapat perbedaan kadar hemoglobin siswa berprestasi dan tidak berprestasi. Untuk mata pelajaran IPA dengan nilai Asympt. Sig 0,028 $<0,05$, artinya terdapat perbedaan antara kadar hemoglobin siswa berprestasi dan tidak berprestasi. Kadar hemoglobin tidak mempengaruhi nilai matematika tapi mempengaruhi nilai IPA.
\end{abstract}

Kata kunci: hemoglobin, defisiensi besi, prestasi siswa. 
Capaian prestasi belajar para siswa dipengaruhi oleh berbagai faktor. Faktorfaktor tersebut bisa sendiri atau bersama dengan faktor lain mempengaruhi proses belajar sehingga menyebabkan penurunan prestasi siswa. Anemia, secara khusus anemia defisiensi besi adalah salah satu masalah utama yang dihadapi para siswa dan memiliki pengaruh negatif terhadap performa dan produktifitas siswa. World Health Organization (WHO) melaporkan bahwa 1,62 miliar populasi mengalami anemia,rata-rata pada umur sekolah yaitu sekitar 25,4 \% dan prasekolah sebesar 47,4 $\%$. Hasil dari studi-studi sebelumnya di beberapa negara memperlihatkan hal yang sama. ${ }^{1}$

Indonesia sendiri, penelitian yang dilakukan oleh Pusponegoro (2006) menemukan anemia pada balita $40.5 \%$, usia sekolah $47.2 \%$, remaja putri $57.1 \%$ dan ibu hamil 50.9\%. Survey Kesehatan Rumah Tangga 2001, mendapatkan prevalensi anemia pada anak $0-5$ tahun $47 \%$, anak sekolah dan remaja 26.5\%, dan wanita usia subur 40\%. ${ }^{1-3}$ Menurut Ikatan Dokter Anak Indonesia tahun 2007 dari 1.000 anak sekolah pada 11 provinsi di Indonesia menunjukan prevalensi anemia sebanyak $20 \%-25 \%$ dan jumlah anak yang mengalami defisiensi besi tanpa anemia jauh lebih banyak.Survey yang dilakukan oleh Mercy Cups tahun 2005 di 4 provinsi ( Sumbar, Riau, Bengkulu dan Lampung ) ditemukan bahwa anak usia sekolah yang menderita anemia sebanyak 45.31\%, mempunyai dampak yang merugikan bagi kesehatan anak, seperti tumbuh kembang, daya tahan tubuh,dan kemampuan belajar, sehingga menurunkan prestasi belajar di sekolah. ${ }^{1,4,5}$

Anemia adalah keadaan yang menunjukkan kadar hemoglobin (Hb) seseorang lebih rendah dari kadar hemoglobin normal. Hal ini disebabkan oleh kekurangan zat besi yang diperlukan untuk pembentukan hemoglobin dalam tubuh. Keadaan anemia menyebabkan kapasitas pengangkutan oksigen oleh sel darah merah menurun.Pada kasus anemia ringan, gejala ditunjukan dengan kondisi anak akan terlihat lesu, mudah lelah, pusing, nafsu makan berkurang, kurang konsentrasi. Namun jika tidak segera diatasi, anak akan mengalami; gangguan pendengaran, penglihatan, lebih emosional, hiperaktif, sulit menerima dan memproses informasi, pelupa, sehingga menghambat proses belajar, akibatnya prestasi di sekolah menurun drastis. ${ }^{6,7}$

Berdasarkan fakta-fakta tersebut, penulis tertarik melakukan penelitian perbedaan hemoglobin antara anak sekolah berprestasi dengan siswa prestasi rendah di SMPN 9 Pandu. Diharapkan penelitian ini dapat menjadi acuan untuk memperbaiki prestasi belajar anak pada aspek defisiensi besi.

\section{METODE PENELITIAN}

Penelitian ini bersifat analitik dengan pendekatan cross sectional. Penelitian ini dilakukan dari bulan November 2013 Desember 2013, Sampel ditentukan menggunakan daftar tabel Krejcie dan Morgan (1970) dalam Uma Sekaran (1992), dengan diketahui jumlah populasi kelas 3 SMP Pandu Kota Manado sebesar 65 siswa, maka jumlah sampel yang diambil sebanyak 56 siswa.

\section{HASIL PENELITIAN}

Penelitian hubungan antara kadar hemoglobin dengan prestasi belajar dilakukan di SMP 9 Pandu, penelitian dilakukan dengan sampel diambil pada kelas 3 berjumlah 56 sampel. Nilai yang diambil di penelitian ini adalah nilai midsemester, karena nilai itu masih dianggap murni, sedangkan nilai semester adalah nilai siswa setelah beberapa kali mengikuti remedial untuk mencapai nilai tertinggi. Jadi nilai mid semester yang diambil untuk dianalisis hubungannya dengan kadar hemoglobin. Sebenarnya nilai yang akan diambil adalah 2 nilai mid semester, namun saat penelitian ini dibuat, semester yang berjalan adalah semester ganjil sehingga hanya ada satu nilai mid semester yang akan dianalisis.

Karena siswa "berprestasi” jika nilai yang diperoleh diatas rerata kelas atau 
sebaliknya yang "kurang berprestasi" dibawah rerata kelas, maka harus dicari lebih dulu nilai rerata kelas dari mata pelajaran yang akan diteliti yaitu Matematika dan IPA.

Dari Tabel 1 terlihat rerata mata pelajaran Matematika sebesar 69; nilai ratarata IPA sebesar 78 (nilai tersebut telah dibulatkan). Selanjutnya siswa dikelompokkan menurut prestasi dimana: prestasi baik bila nilai diatas rata-rata 69 untuk matematika; dan 78 untuk IPA. Sebaliknya siswa yang kurang berpretasi bila nilai berada dibawah rerata kelas. Data tersebut kemudian dihubungkan dengan nilai hemoglobin (Tabel 2).

Tabel 1. Rerata mata pelajaran Matematika dan IPA

\begin{tabular}{llrr}
\hline & & Matematika & \multicolumn{1}{c}{ IPA } \\
\hline Total & Mean & 69.2500 & 77.7857 \\
& $\mathrm{~N}$ & 56 & 56 \\
& Std. & 12.38070 & 16.51524 \\
& Deviation & & \\
\hline
\end{tabular}

Tabel 2 menunjukkan bahwa pada mata pelajaran matematika Hb Normal dan berprestasi sebanyak 31 orang sedangkan yang kurang berprestasi 24 orang; pada mata pelajaran IPA, yang berprestasi sebanyak 33 orang sedangkan yang kurang berprestasi 22 orang

Dari Tabel 2 ditemukan bahwa: pada mata pelajaran Matematika jumlah yang berprestasi lebih besar yaitu 57,1 \%, sedangkan mata pelajaran IPA sebesar $58,9 \%)$.

Tabel 2. Distribusi tingkat prestasi siswa pada mata pelajaran matematika dan IPA dihubungkan dengan nilai $\mathrm{Hb}$

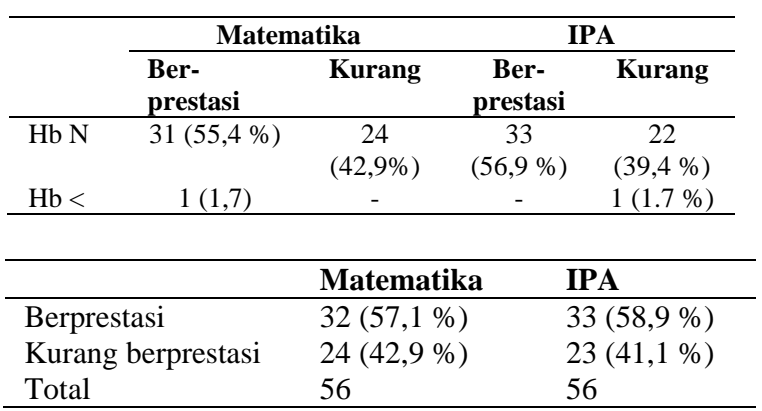

Uji normalitas data apakah terdistribusi normal atau tidak, digunakan uji Kolmogorov-Smirnov test 1 sampel dengan hasil sebagai berikut:

Tabel 3. Uji sampel menggunakan uji Kolmogorov-Smirnov

One-Sample Kolmogorov-Smirnov Test

\begin{tabular}{|c|c|c|c|}
\hline & & Matematika & $\begin{array}{l}\text { IP } \\
\text { A }\end{array}$ \\
\hline $\mathrm{N}$ & & 56 & 56 \\
\hline & Mean & 69.25 & 77. \\
\hline $\begin{array}{l}\text { Normal } \\
\text { Parameters a,b }\end{array}$ & Std & & 19 \\
\hline & Deviation & 12.381 & $\begin{array}{r}10 . \\
515\end{array}$ \\
\hline & Absolute & .236 & $\begin{array}{r}.16 \\
5\end{array}$ \\
\hline Most Extreme & Positive & .148 & .13 \\
\hline & & & \\
\hline & Negative & -.236 & .16 \\
\hline & & 1760 & 1.2 \\
\hline Kolmogorov-S & ov Z & & 36 \\
\hline Asymp. Sig. (2 & & .004 & $\begin{array}{r}.09 \\
4\end{array}$ \\
\hline
\end{tabular}

a. Test distribution is Normal.

b. Calculated from data.

Seperti terlihat pada Tabel 3 bahwa nilai Asympt.Sig. (2-tailed) < 0,05 maka dapat dikatakan bahwa data matematika tidak terdistribusi dengan normal, sedangkan IPA menunjukkan angka Asymp. Sig.(2-tailed) > 0,05 maka dikatakan bahwa data IPA terdistribusi dengan normal. Uji Kruskal-Wallis digunakan untuk mencari apakah benar terdapat perbedaan hemoglobin antara siswa yang berprestasi dan tidak berprestasi: ${ }^{8,9}$ Dalam uji Kruskal-Wallis perlu dicari mean rank dari siswa berprestasi dan kurang berprestasi pada masing-masing mata pelajaran.

Tabel 4 memaparkan analisis hipotesis bahwa nilai Asymp. Sig 0,746> $\alpha$ sehingga Ho diterima, artinya tidak terdapat perbedaan kadar hemoglobin pada siswa yang berpretasi dan tidak berprestasi.

Dari Tabel 5 tes IPA memaparkan analisis hipotesis terlihat bahwa nilai dari Asymp. Sig sebesar $0,028<\alpha$ sehingga $\mathrm{H} 0$ ditolak yang berarti bahwa terdapat 
perbedaan kadar hemoglobin pada siswa yang berpretasi dan tidak berprestasi.

Tabel 4. Uji Kruskal-Wallis untuk mata pelajaran matematika

\begin{tabular}{lrr} 
& \multicolumn{2}{c}{ Ranks } \\
\hline Matematika & N & \multicolumn{2}{c}{ Mean Rank } \\
\hline berprestasi & 32 & 27.89 \\
Kurang & 24 & 29.31 \\
Total & 56 & \\
\hline
\end{tabular}

\begin{tabular}{lr}
\multicolumn{2}{c}{ Test Statistik $^{\mathbf{a}, \mathbf{b}}$} \\
\hline \multicolumn{2}{c}{ Hemoglobin $^{2}$} \\
\hline Chi-Square & .105 \\
Df & 1 \\
Asymp. Sig. & .746 \\
\hline
\end{tabular}

a. Kruskal Wallis Test

b. Grouping Variable: Matematika

Tabel 5. Uji Kruskal-Wallis untuk mata pelajaran IPA

\begin{tabular}{lrr}
\multicolumn{3}{c}{ Ranks } \\
\hline IPA & N & Mean Rank \\
\hline berprestasi & 33 & 32.74 \\
Kurang & 23 & 22.41 \\
Total & 56 & \\
\hline
\end{tabular}

\begin{tabular}{lr}
\multicolumn{2}{c}{ Test Statistik $^{\mathbf{a}, \mathbf{b}}$} \\
\hline \multicolumn{2}{c}{ Hemoglobin $^{2}$} \\
\hline Chi-Square & 5.453 \\
Df & 1 \\
Asymp. Sig. & .020 \\
\hline
\end{tabular}

a. Kruskal Wallis Test

b. Grouping Variable: IPA

\section{BAHASAN}

Dari hasil penelitian dan interpretasi data, ditemukan bahwa; pertama, pada mata pelajaran matematika dalam penelitian ini tidak terdapat perbedaan kadar hemoglobin yang signifikan antara siswa yang berprestasi dengan yang tidak berprestasi. Artinya dalam penelitian ini kadar hemoglobin tidak terlihat mempengaruhi prestasi siswa. Kedua, pada mata pelajaran IPA, terdapat perbedaan kadar hemoglobin antara siswa yang berprestasi dengan tidak berprestasi. Artinya kadar hemoglobin mempengaruhi prestasi belajar siswa.

Anemia defisiensi besi adalah kekurangan gizi yang paling umum di seluruh dunia, mempengaruhi sekitar seperempat dari populasi global dan sangat luas di negara-negara berkembang. Kekurangan zat besi menghambat transportasi oksigen antara otak dan tubuh, dibawa oleh hemoglobin $(\mathrm{Hb})$ protein dalam sel darah merah. Dalam kasus yang parah, anemia dapat mengancam jiwa karena kehilangan darah atau gagal jantung. Banyak aspek penting dari kesehatan manusia yang terpengaruh oleh anemia, termasuk energi, pengaturan suhu, perilaku, dan fungsi kekebalan tubuh. Selain itu, banyak penelitian telah mengaitkan kekurangan zat besi kurang ekstrim dan anemia untuk gangguan kognitif dan fungsi otak diubah. ${ }^{3}$

Beberapa penelitian sebelumnya yang dilakukan pada siswa perempuan kelas tiga SMA di Iran menemukan adanya hubungan yang positif antara 6 faktor darah (ferritin, besi serum, MCV, MCHC, HCT dan hemoglobin) dengan capaian belajar siswa. ${ }^{1}$ Penelitian lain menunjukkan bahwa intake besi memiliki efek positif terhadap konsentrasi kekuatan mental dan memperbaiki kemampuan belajar siswa dibandingkan dengan kelompok kontrol. ${ }^{10}$ Pemberian suplementasi besi pada imigran di Kanada menemukan adanya perbaikan performa kognitif khususnya pada anakanak dalam derajat yang sedang. ${ }^{11}$

Anemia terutama disebabkan oleh nutrisi yang buruk. Fakta yang ada menunjukkan bahwa penyakit kronik yang paling sering terjadi pada manusia adalah anemia defisiensi besi dan 30 persen populasi di seluruh dunia dipengaruhi. ${ }^{1}$ Enzim otak adalah fungsi tubuh pertama kali yang dipengaruhi oleh defisiensi besi, dimana berhubungan dengan perilaku dan kognitif. $^{12}$ Apatis, kelemahan, kehilangan kekuatan dan kemauan terhadap aktifitas fisik seperti olah raga, adalah tanda yang harus diketahui oleh guru dan orang tua bahwa terjadi anemia defisiensi besi pada anak. Kecukupan besi sangat esensial bagi pertumbuhan. Defisiensi dalam seluruh stadium kehidupan dapat mengurangi kemampuan persepsi dan belajar. ${ }^{1}$ 
Terdapat interaksi yang kompleks dari faktor-faktor sistemik, kultural dan individu yang memberikan kontribusi terhadap defisiensi besi. Intervensi untuk memperbaiki status besi dan mencegah kejadian ulang meliputi modifikasi diet yang didukung oleh edukasi makanan. Mengurangi makanan yang dapat mengikat besi dan penambahan sumber vitamin $\mathrm{C}$ dapat memperbaiki status besi. ${ }^{10,11}$

Suplementasi besi sangat penting untuk mencegah anemia defisiensi besi pada anak sekolah terutama di negaranegara miskin. Dua kategori suplementasi besi, yaitu suplemen yang mengandung bentuk ferrous dan suplemen dengan bentuk ferric besi. Suplementasi yang paling banyak digunakan adalah yang mengandung bentuk ferrous karena lebih mudah diabsorbsi. Tiga tipe suplementasi besi ferrous: ferrous fumarat, ferrous sulfat, dan ferrous glukonat, dimana ketiganya berbeda dalam jumlah elemen besi (bentuk besi dalam suplemen yang tersedia untuk absorbsi oleh tubuh), dan mengandung masing-masing $33 \%$, $20 \%$ dan $12 \%$ besi. Dosis harian yang direkomendasikan oleh Center for Disease Control and Prevention (CDC), berkisar dari 150 - $180 \mathrm{mg} / \mathrm{hari}$ dari elemen besi yang diberikan dalam dosis terbagi 2 atau 3 kali sehari. Hitung retikulosit mulai meningkat diantara minggu pertama terapi besi, sedangkan hemoglobin biasanya lebih lama berkisar 12 minggu. Suplemen besi oral sangat penting sebagai terapi first-line oleh karena keamanan, murah dan efektif dalam mengembalikan keseimbangan besi. ${ }^{12}$

Beberapa kelemahan studi ini; pertama, terletak pada waktu pengambilan sampel, yaitu pada semester ganjil sehingga hanya menggunakan 1 nilai saja sehingga mungkin tidak mewakili keseluruhan prestasi belajar siswa.Kedua, pengujian ini tidak dilakukan secara langsung pada siswa berprestasi dan tidak berprestasi, tapi diambil secara acak tanpa memperhatikan status besi sampel. Ketiga, jarak waktu pengambilan sampel darah dengan mid semester yang cukup jauh yaitu sekitar 3 bulan, sedangkan peningkatan $\mathrm{Hb}$ rata-rata antara 1-2 minggu dengan suplementasi. ${ }^{12}$ Jarak waktu yang cukup lama bisa mempengaruhi hasil pengukuran $\mathrm{Hb}$. Faktor-faktor lain bisa mempengaruhi hasil $\mathrm{Hb}$ responden, misalnya intake besi dari makanan atau dari suplementasi yang cukup atau berlebihan,dimana sebelumnya mungkin rendah.

\section{SIMPULAN}

Dari hasil penelitian hubungan antara kadar hemoglobin dengan prestasi belajar siswa dapat ditarik kesimpulan bahwa:

1. Pada mata pelajaran matematika, tidak terdapat perbedaan kadar hemoglobin siswa berprestasi dan kurang berprestasi.

2. Pada mata pelajaran IPA, terdapat perbedaan kadar hemoglobin siswa berprestasi dan kurang berprestasi.

\section{DAFTAR PUSTAKA}

1. Soleimani N, Abbaszadeh N. Relationship betwen anemia, cause from iron deficiency, and academic achievement among third grade high school female students. International Conference on Education and Educational Psychology. Elsevier; 2011. p. 1877-84.

2. Abalkhail B, Shawky S. Prevalence of daily breakfast intake, iron deficiency anaemia and awareness of being anaemic among Saudi school students. IntJ Food Sci Nutr. 2009;53:519-28.

3. Luo R, Zhang L, Liu C, Zhao Q, Shi Y, Miller G, et al. Anaemia among students of rural China's Elementary Schools: prevalence and correlates in Ningxia and Qinghai's poor countries. JHPN. 2011;29:471-85.

4. Bobonis GJ, Miguel E, Puri-Sharma C. Anemia and school participation. Forthcoming J Hum Res. 2009;1-46.

5. Gunde R. School children in the developing world: health, nutrition and school performance. A two-day international workshop under the Global Impact Research Initiative. UCLA International Institute; 2008.

6. Hurley R. Chronic illness in immigrants: anemia and red blood cell disorders. 
In: Walker $\mathrm{P}$, Barnett $\mathrm{E}$, editors. Immigrant medicine. Philadelphia (PA): Saunders Elsevier; 2007.p 1-5.

7. Alton I. Iron deficiency anemia. Guidelines for adolescent nutrition services. Guidelines for Adolescent Nutrition Services. 2005; [cited 2013 October 18]. Available from: http://www.epi.umn.edu/let/pubs/adol book.shtm.

8. Santoso S. Statistik nonparametrik. Konsep dan aplikasi dengan SPSS. Elex Media Komputindo, 2011. p 219-271.

9. McCann JC, Ames BN. An overview of evidencefor a causal relation between irondeficiency during development and deficits in cognitive or behavioral function. Am JClin Nutr. 2007;85:931-45
10.Pottie K, Chamber A, Brockest B, Welch V, Zlotkin S. Iron-deficiency anemia: evidence review for newly arriving immigrants and refugees. Guidelines for immigrant health. Canadian Collaboration for Immigrant and Refugee Health (CCIRH). CMAJ. 2011;15:1-13.

11.Nevins S. Massachusetts institute of technology and director, food and nutrition program for human andsocial development united nations. University of Tokyo. 2008;18:351-79.

12.Johnson TD, Graham DY. Diagnosis and management of iron deficiency anemia in the $21^{\text {st }}$ century. Ther Adv Gastroenterol. 2011;4:177-84 